\title{
PENERAPAN METODE DOUBLE EXPONENTIAL SMOOTHING PADA PERAMALAN PRODUKSI TANAMAN PANGAN
}

\author{
Rudy Ariyanto ${ }^{1}$, Dwi Puspitasari², Fifi Ericawati ${ }^{3}$ \\ 1,2,3 Program Studi Teknik Informatika, Jurusan Teknologi Informasi, Politeknik Negeri Malang \\ 1ariyantorudy@gmail.com,2dwi_sti@yahoo.com,3fifierica24@gmail.com
}

\begin{abstract}
Abstrak
Produksi pangan adalah salah satu aspek kebutuhan yang sangat penting. Ketersediaan pangan mempengaruhi stabilitas ketahanan pangan. Beberapa komoditas tanaman pangan yang menjadi kebutuhan pokok adalah Padi, Jagung, Kedelai, dan Ubi Kayu, Ubi Jalar, Kacang Tanah dan Kacang Hijau. Jumlah produksi pangan yang tidak menentu menjadi suatu masalah bagi Badan Ketahanan Pangan (BKP) Provinsi Jawa Timur dalam menentukan kebijakan mendatang. Apabila prediksi tidak diketahui maka dalam pembangunan Ketahanan Pangan dipastikan kurang maksimal dan alhasil Indonesia melakukan impor karena belum bisa memenuhi kebutuhan pangan. Diperlukan suatu peramalan dalam memprediksi produksi tanaman pangan di periode mendatang berdasarkan tahun dengan menggunakan data masa lalu. Sehingga dari pergerakan data masa lalu dapat dianalisa pergerakan trend. Peramalan diterapkan dengan menggunakan Double Exponential Smoothing Holt dengan menggunakan 2 parameter yaitu alpha $(\alpha)$ dan beta $(\beta)$. Pada penelitian ini peramalan menggunakan data komoditas padi dengan range waktu sebanyak 22 periode berdasarkan tahun. Data tahun 1993-2014 untuk ramalan 2015 menghasilkan nilai parameter alpha $(\alpha)=0.46$ dan beta $(\beta)=0.26$, sehingga parameter mempengaruhi nilai PE. Nilai PE yang dihasilkan pada penelitian ini cenderung memiliki nilai PE yang kecil yaitu $2.22 \%$.
\end{abstract}

Kata kunci : Komoditas, Peramalan, BKP, Double Exponential Smoothing

\section{Pendahuluan}

Indonesia merupakan salah satu negara agraris dengan luas lahan yang luas yaitu dengan luas $1.910 .931,32 \mathrm{~km} 2$ dari 663 pulau yang tersebar di Indonesia dan memiliki keanekaragaman hayati yang sangat beragam yang artinya sektor pertanian memiliki peranan yang sangat penting dan strategis dalam pembangunan nasional. Dalam konteks pangan, perkembangan kuantitas penduduk Indonesia membawa dampak pada perubahan kebutuhan dan produksi pangan nasional. Kebutuhan pangan bertambah seiring pertambahan jumlah penduduk.

Jumlah produksi pangan yang tidak menentu menjadi suatu masalah bagi Badan Ketahanan Pangan (BKP) Provinsi Jawa Timur dalam menentukan kebijakan mendatang. Serta kesulitan dalam memprediksi konstribusi produksi tanaman pangan Jawa Timur terhadap Nasional. Tanaman pangan diantaranya padi, jagung, kedelai, ubi kayu, ubi jalar, kacang tanah, dan kacang hijau. Apabila prediksi tidak diketahui maka dalam pembangunan Ketahanan Pangan dipastikan kurang maksimal dan alhasil Indonesia melakukan impor karena belum bisa memenuhi kebutuhan pangan.

Untuk menyelaraskan hasil peramalan dalam bentuk seperti demikian, perlu dibangun suatu sistem peramalan untuk mengetahui tingkat produksi tanaman pangan di masa mendatang sesuai dengan hasil panen sehingga didapatkan hasil yang optimal pada setiap peramalan dan dapat menjadi acuan untuk mengetahui produksi tanaman pangan mana yang harus ditingkatkan lagi agar jumlah tanaman pangan dapat meningkat kedepannya.

Dalam membangun suatu sistem peramalan banyak metode yang digunakan diantaranya Moving Average, Exponential Smoothing dan proyeksi Trend. Salah satu metode yang diterapkan dalam sistem peramalan jumlah produksi tanaman pangan studi kasus Badan Ketahanan Pangan Provinsi Jawa Timur yaitu menggunakan metode Exponential Smoothing, dimana metode ini dinyatakan cukup sesuai untuk peramalan jangka pendek dan jangka menengah terutama bila dibutuhkan sejumlah besar hasil ramalan seperti yang terdapat pada tingkat operasional suatu perusahaan Makridakis, Spyros., Wheelwright, Steven C., and McGee, Victor E (1999). Di buku Makridakis, Spyros., Wheelwright, Steven C., and McGee, Victor E (1999) Ditunjang dengan data yang menunjukkan suatu trend linear maka model linear dari Holt atau Brown adalah tepat sehingga jenis dari metode Exponential Smoothing yaitu Double Exponential Smoothing. Selain itu berdasarkan perbandingan dari berbagai metode pemulusan (Smoothing) menunjukkan bahwa tingkat keakurasian metode Double Exponential Smoothing dari Holt lebih tinggi dari pada metode Double 
Exponential Smoothing dari Brown sehingga metode Double Exponential Smoothing dari Holt digunakan untuk memprediksi jumlah produksi tanaman pangan di Jawa Timur yang akan terjadi dimasa depan apakah mengalami peningkatan ataukah mengalami penurunan. Maka dengan adanya sistem peramalan ini, masalah dan hambatan tersebut dapat diprediksi.

\section{Peramalan}

Peramalan adalah seni dan ilmu memprediksi peristiwa-peristiwa yang akan terjadi dengan menggunakan data historis dan memproyeksikannya ke masa depan dengan beberapa bentuk model matematis, Bina Nusantara (2005). Untuk melakukan peramalan diperlukan metode tertentu dan metode mana yang digunakan tergantung dari data dan informasi yang akan diramal serta tujuan yang hendak dicapai.

\section{Double Exponential Smoothing Holt}

Metode pemulusan eksponensial linier dari Holt pada prinsipnya serupa dengan Brown kecuali bahwa Holt tidak menggunakan rumus pemulusan berganda secara langsung. Sebagai gantinya, Holt memutuskan nilai trend dengan parameter yang berbeda dari dua parameter yang digunakan pada deret yang asli.

Ramalan dari pemulusan eksponensial linier Holt didapat dengan menggunakan tiga persamaan, yaitu:

$$
\begin{aligned}
& S^{\prime}{ }_{t}=\alpha X_{t}+(1-\alpha)\left(S^{\prime}{ }_{t-1}+\mathrm{t}_{\mathrm{t}-1}\right) \\
& t_{t}=\beta(1) \\
& F_{t+m}{ }_{t}{ }_{t}-S^{\prime}{ }_{t}{ }_{t}+t_{t} m
\end{aligned}
$$

Inialisasi :

$$
\begin{aligned}
& S_{1}^{\prime}=X_{1} \\
& t_{1}=\frac{\left(X_{2}-X_{1}\right)+\left(X_{4}-X_{3}\right)}{2}
\end{aligned}
$$

$$
\begin{aligned}
\underset{\text { Dimana: }}{\mathrm{X}_{\mathrm{t}}}= & \text { Data demand pada periode } \mathrm{t} \\
\mathrm{S}_{\mathrm{t}}= & \text { nilai single exponential } \\
& \text { smoothing } \\
\mathrm{t}_{\mathrm{t}} & \text { Nilai trend pada periode ke }-\mathrm{t} \\
\alpha, \beta= & \text { parameter pemulusan antara } 0-1 \\
\mathrm{~F}_{\mathrm{t}+\mathrm{m}}= & \text { ramalan m periode yang akan } \\
& \\
\mathrm{m} & \text { diramalkan } \\
& \text { jumlah periode ke muka yang } \\
& \text { akan diramalkan }
\end{aligned}
$$

\section{Ketepatan Metode Peramalan}

Dalam semua situasi peramalan mengandung derajat ketidakpastian. Jika $\mathrm{Xi}$ merupakan data aktual untuk periode $\mathrm{i}$ dan Fi merupakan ramalan (atau nilai kecocokan/fitted value) untuk periode yang sama, kesalahan didefinisikan sebagai :

$$
e_{i}=X_{i}-F_{i}
$$

Jika terdapat nilai pengamatan dan ramalan untuk $n$ periode waktu, akan terdapat $\mathrm{n}$ buah galat dan ukuran statistik standar di dalam buku Makridakis, Spyros., Wheelwright, Steven C., and McGee, Victor E (1999) yang dapat didefinisikan:

a. Kesalahan Presentase / Percentage Error (PE)

$$
P E_{i}=\frac{X_{i}-F_{i}}{X_{i}} x 100 \%
$$

b. Jumlah Kuadrat Galat (Sum Of Squared Error)

$$
S S E=\sum_{i=1}^{n} e_{i}^{2}
$$

\section{Desain Penelitian}

Metodologi penelitian akan dijelaskan dalam penelitian tentang meramalkan produksi tanaman pangan menggunakan metode Double Exponential Smoothing Holt. Adapun tahapannya, yaitu :

1. Mempelajari literature yang berhubungan dengan peramalan menggunakan metode Double Exponential Smoothing Holt.

2. Melakukan analisa kebutuhan.

3. Menganalisa dan melakukan perancangan sistem

4. Membuat sistem berdasarkan analisis dan perancangan yang telah dilakukan.

5. Melakukan uji coba terhadap sistem yang telah dibuat.

6. Mengevaluasi dan menganalisis hasil peramalan.

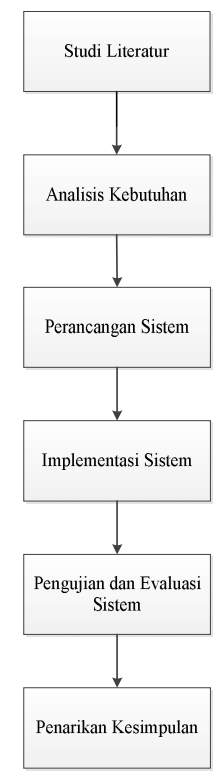

Gambar 1. Langkah-Langkah Penelitian

\section{Gambaran Sistem}

Sistem peramalan produksi tanaman pangan merupakan sistem yang memakai data masa lampau 
atau data history dalam menentukan kejadian masa depan dalam bentuk perhitungan atau prakiraan dengan menggunakan metode Double Exponential Smoothing Holt dimana akan berbasis Website menggunakan Bahasa pemrograman PHP, Javascript, CSS dan HTML dalam pengembanganya. Sistem ini terbagi menjadi dua subsistem yang saling berintegrasi yakni Sub Sistem Pengolahan Data dan Dan Sub Sistem Peramalan, seperti yang digambarkan pada Gambar 2.

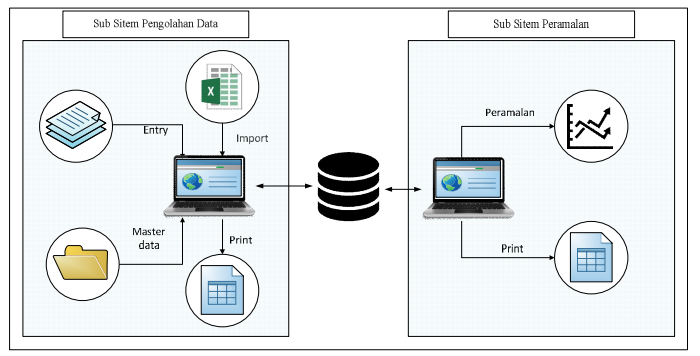

Gambar 2. Block Diagram Sistem

\subsection{Sub Sistem Pengolahan Data}

Sub sistem pengolahan data ini merupakan bagian sub sistem yang diperuntukkan oleh Badan Pusat Statistika dimana memberikan pelayanan dalam memanajemen informasi yang dibutuhkan dalam pengolahan atau penginputan data produksi tanaman di setiap kota.

\subsection{Sub Sistem Peramalan}

Sub sistem peramalan produksi tanaman pangan ini diperuntukkan oleh Badan Ketahanan Pangan menggunakan metode Double Exponential Smoothing Holt merupakan sebuah sistem yang dapat memprediksi produksi tanaman pangan pada periode berikutnya berdasarkan tahun.

\section{Analisa Proses}

Pengolahan data sebelum diterima oleh instansi yang bersangkutan, ada beberapa aktor yang terlibat di dalamnya seperti pada Gambar 3. Diantaranya Operator setiap kota, IPDS setiap Kota/Kabupaten, IPDS setiap Provinsi dan IPDS Pusat.

Operator merupakan pengelola data produksi tanaman pangan di masing-masing kabupaten atau kota yang dapat melakukan input pemasukan data, IPDS Kota merupakan pengelola data produksi tanaman pangan di masing-masing kabupaten atau kota yang dapat melakukan input pemasukan data, IPDS Provinsi merupakan pengelola data produksi tanaman pangan di masing-masing provinsi yang dapat melakukan validasi data, IPDS Pusat merupakan pengelola data master terhadap data yang telah diinputkan. Dan Instansi merupakan instansi yang mengambil data atau informasi yang telah disediakan.

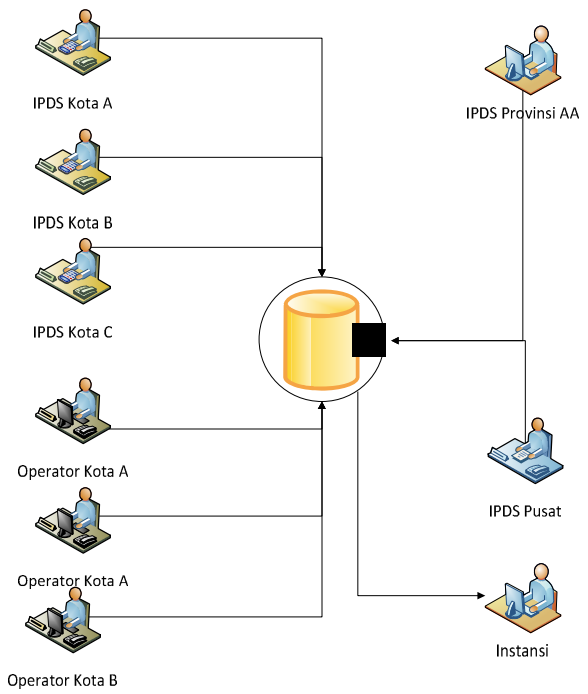

Gambar 3. Arsitektur

\section{Metode Double Exponential Smoothing Holt}

Algoritma merupakan alur berjalannya suatu proses pada sistem secara logis yang bertujuan untuk menyelesaikan masalah. Pada sistem peramalan ini terdapat proses perhitungan setiap metode. Pada sub bab ini akan dijelaskan bagaimana alur perhitungan peramalan setiap metode hingga menemukan hasil akhir. Terdapat metode yang dihitung, yaitu Double Exponential Smoothing Holt.

Berikut ini adalah flowchart dari Double Exponential Smoothing Holt :

\section{Perhitungan Metode}

Berikut merupakan tahapan dalam perhitungan metode Double Exponential Smoothing Holt yang diimplementasikan pada source code yaitu :

1) Melakukan persiapan data history untuk dilakukan perhitungan.

2) Melakukan pemasangan 2 parameter yang berbeda, nilai parameter hanya ditentukan pada range $1<(\alpha)>0$ dan $1<(\beta)>0$ sehingga dalam penentuan parameter dapat memberikan nilai bebas diantara range yang ditentukan, Melakukan perhitungan inialisasi pada $S^{\prime}{ }_{1}$ dengan menggunakan rumus pada persamaan (4)

3) Melakukan perhitungan inialisasi pada $t_{1}$ dengan menggunakan rumus pada persamaan (5)

4) Melakukan perhitungan inialisasi pada $S_{n, \quad n \neq 1}^{\prime}$ dengan menggunakan rumus pada persamaan (1)

5) Melakukan perhitungan inialisasi pada $t_{n, n \neq 1}$ dengan menggunakan rumus pada persamaan (2)

6) Melakukan perhitungan nilai ramalan dengan menggunakan rumus pada persamaan (2) 
7) Melakukan perhitungan error dengan menggunakan rumus pada persamaan (5)

8) Melakukan perhitungan nilai PE dengan menggunakan rumus pada persamaan (7)

9) Melakukan perhitungan Error ${ }^{2}$ dengan menggunakan perhitungan dari hasil error dikuadratkan.

10)Melakukan perhitungan nilai SSE setelah menghitung dari periode 1- 14 , setalah perhitungan selesai maka dilakukan perhitungan SSE dengan menggunakan rumus pada persamaan (8)

11) Setelah perhitungan $1-11$ telah dilakukan, melakukan perhitungan dalam mencari alpha $(\alpha)$ dan beta $(\beta)$ secara dinamis. Perhitungan dari perhitungan beta $(\beta)$ awal +0.1 untuk nilai parameter beta $(\beta)$ berikutnya dan begitu juga untuk nilai alpha $(\alpha)$ awal +0.1 untuk nilai parameter alpha $(\alpha)$.

12) Melakukan pengulangan perhitungan pada nomor 2-11 dengan menggunakan 2 parameter yang berbeda sampai 81 perhitungan

13) Melakukan pencarian nilai minimum SSE

14) Mencari nilai atau posisi index alpha $(\alpha)$ baru dan beta $(\beta)$ baru sesuai nilai SSEmin.

15) Melakukan pemasangan alpha $(\alpha)$ dan beta $(\beta)$ yang baru sesuai dengan nilai SSE minimum.

16)Kemudian melakukan perhitungan kembali dari no 2 - 11 dari periode 1 sampai periode 14 .

17) Terakhir melakukan perhitungan hasil ramalan pada periode ke-15 dengan menggunakan rumus pada persamaan (3).

\section{Analisa Penelitian}

Pada pengujian metode Double Exponential Smoothing Holt, penulis melakukan pengujian terhadap penyimpangan rentan jumlah data yang digunakan sebagai data histori. Nilai penyimpangan didapat dari perhitungan selisih dari data asli dengan data peramalan yang dihasilkan, sehingga dapat mengetahui nilai penyimpanyan dalam bentuk persen. Pengujian ini juga untuk mengetahui nilai alpha $(\alpha)$ dan beta $(\beta)$ yang digunakan pada setiap proses karena pada sistem ini alpha $(\alpha)$ dan beta $(\beta)$ berproses secara dinamis sesuai dengan SSE terkecil yang dihasilkan.

Berikut analisa kesalahan yang dapat dilihat pada Tabel 1 yaitu dari periode 1 sampai periode 22 dengan menggunakan data komoditas Padi dimana periode 23 berada pada posisi tahun 2015 dengan jumlah produksi dalam angka adalah 13154967. Pada Tabel 6 menunjukkan nilai ramalan periode 23 memiliki nilai ramalan 12863133.09. Hasil ramalan pada periode 23 dengan menggunakan periode 1 sampai 23 diperoleh nilai sebagai berikut :

$$
\begin{array}{ll}
\operatorname{alpha}(\alpha) & =0.46 \\
\operatorname{beta}(\beta) & =0.26 \\
\mathrm{SSE} & =1.18014 \mathrm{E}+13 \\
\mathrm{PE} & =2.22 \%
\end{array}
$$

\section{Kesimpulan dan Saran}

\subsection{Kesimpulan}

Berdasarkan pengujian yang telah dilakukan oleh penulis pada penerapan metode Double Exponential Smoothing Holt pada peramalan jumlah produksi tanaman pangan studi kasus Badan Ketahanan Pangan Provinsi Jawa Timur dapat diambil beberapa kesimpulan sebagai berikut:

1. Sistem peramalan ini dapat digunakan untuk mengetahui prediksi atau peramalan pada masa mendatang berdasarkan tahun di Jawa Timur, sehingga dapat membantu Badan Ketahanan Pangan Provinsi Jawa Timur untuk menentukan pengambilan kebijakan kedepannya.

2. Jumlah data atau range waktu yang digunakan dalam peramalan mempengaruhi hasil alpha $(\alpha)$ dan beta $(\beta)$, dimana alpha $(\alpha)$ dan beta $(\beta)$ itu dapat mempengaruhi hasil nilai ramalan dan $\mathrm{PE}$ yang dihasilkan. Semakin panjang range waktu yang digunakan untuk meramal, maka akan mengasilkan peramalan yang cenderung menghasilkan nilai PE yang kecil.

\subsection{Saran}

Saran yang diberikan untuk pengembangan sistem pada penelitian selanjutnya adalah, penelitian ini hanya pada lingkup Provinsi Jawa Timur. Untuk penelitian selanjutnya diharapkan bisa pada lingkup di berbagai provinsi.

\section{Daftar Pustaka:}

Bina Nusantara, 2005, Peramalan Produk [Online], Tersedia:repository.binus.ac.id/content/F0532/ F053299233.ppt [28 Deember 2016].

Bowerman, B. L. \& O'Connell, R.T, 1987, Time Series Forecasting, Boston: Duxbury Press.

Data Sensus Penduduk, Tersedia: https://www.bps.go.id/ site/pilihdata, [27 Desember 2016].

Data Tanaman Pangan Provinsi Jawa Timur, Tersedia: : http://data.go.id/dataset [19 Desember 2016].

Makridakis. Spyros, Wheelwright. Steven C, dan McGee. Victor E,1999, Metode Dan Aplikasi Peramalan, Jakarta: Penerbit Erlangga.

Nurdina. Awwaliyah, dan Mahmudah, 2014, Penerapan Metode Double Exponential Smoothing Dalam Meramalkan Jumlah Penderita Kusta Di Kabupaten Pasuruan. 
Tabel 1. Tabel Pengujian Padi

\begin{tabular}{|c|c|c|c|c|c|c|c|}
\hline Tahun & Periode & Padi & St & $\mathrm{T}_{\mathrm{t}}$ & Forecast & Error & $\begin{array}{c}\text { Presentase } \\
\text { Error }\end{array}$ \\
\hline 1993 & 1 & 8627784 & 8627784 & -137669 & & & \\
\hline 1994 & 2 & 8296348 & 8400982.18 & -160843.5332 & 8490115 & -193767 & $-2.34 \%$ \\
\hline 1995 & 3 & 8572668 & 8393102.149 & -121073.0226 & 8240138.647 & 332529.3532 & $3.88 \%$ \\
\hline 1996 & 4 & 8628766 & 8436128.088 & -78407.29251 & 8272029.127 & 356736.8733 & $4.13 \%$ \\
\hline 1997 & 5 & 8533839 & 8438735.17 & -57343.5553 & 8357720.796 & 176118.2041 & $2.06 \%$ \\
\hline 1998 & 6 & 8691519 & 8524050.212 & -20252.32 & 8381391.614 & 310127.3855 & $3.57 \%$ \\
\hline 1999 & 7 & 8956196 & 8711901.022 & 33854.49374 & 8503797.892 & 452398.1082 & $5.05 \%$ \\
\hline 2000 & 8 & 9224353 & 8965910.358 & 91094.75291 & 8745755.515 & 478597.4847 & $5.19 \%$ \\
\hline 2001 & 9 & 8672791 & 8880266.62 & 45142.74521 & 9057005.111 & -384214.1112 & $-4.43 \%$ \\
\hline 2002 & 10 & 8803878 & 8869504.937 & 30607.59393 & 8925409.365 & -121531.3652 & $-1.38 \%$ \\
\hline 2003 & 11 & 8914995 & 8906958.467 & 32387.5372 & 8900112.531 & 14882.46884 & $0.17 \%$ \\
\hline 2004 & 12 & 9002025 & 8968178.342 & 39883.94512 & 8939346.004 & 62678.99597 & $0.70 \%$ \\
\hline 2005 & 13 & 9007265 & 9007695.535 & 39788.58956 & 9008062.287 & -797.2872918 & $-0.01 \%$ \\
\hline 2006 & 14 & 9346947 & 9185237.047 & 75604.34944 & 9047484.125 & 299462.8753 & $3.20 \%$ \\
\hline 2007 & 15 & 7932751 & 8649919.814 & -83235.26201 & 9260841.397 & -1328090.397 & $-16.74 \%$ \\
\hline 2008 & 16 & 10474773 & 9444405.238 & 144972.1163 & 8566684.552 & 1908088.448 & $18.22 \%$ \\
\hline 2009 & 17 & 11259085 & 10357442.87 & 344669.1507 & 9589377.355 & 1669707.645 & $14.83 \%$ \\
\hline 2010 & 18 & 11643773 & 11135276.07 & 457291.8037 & 10702112.02 & 941660.9778 & $8.09 \%$ \\
\hline 2011 & 19 & 10576543 & 11125196.43 & 335775.2286 & 11592567.88 & -1016024.876 & $-9.61 \%$ \\
\hline 2012 & 20 & 12198707 & 11800329.92 & 424008.375 & 11460971.66 & 737735.3386 & $6.05 \%$ \\
\hline 2013 & 21 & 12049342 & 12143840 & 403078.8185 & 12224338.29 & -174996.2922 & $-1.45 \%$ \\
\hline 2014 & 22 & 12397049 & 12477978.7 & 385154.3885 & 12546918.82 & -149869.8163 & $-1.21 \%$ \\
\hline 2015 & 23 & & & & 12863133.09 & & \\
\hline
\end{tabular}



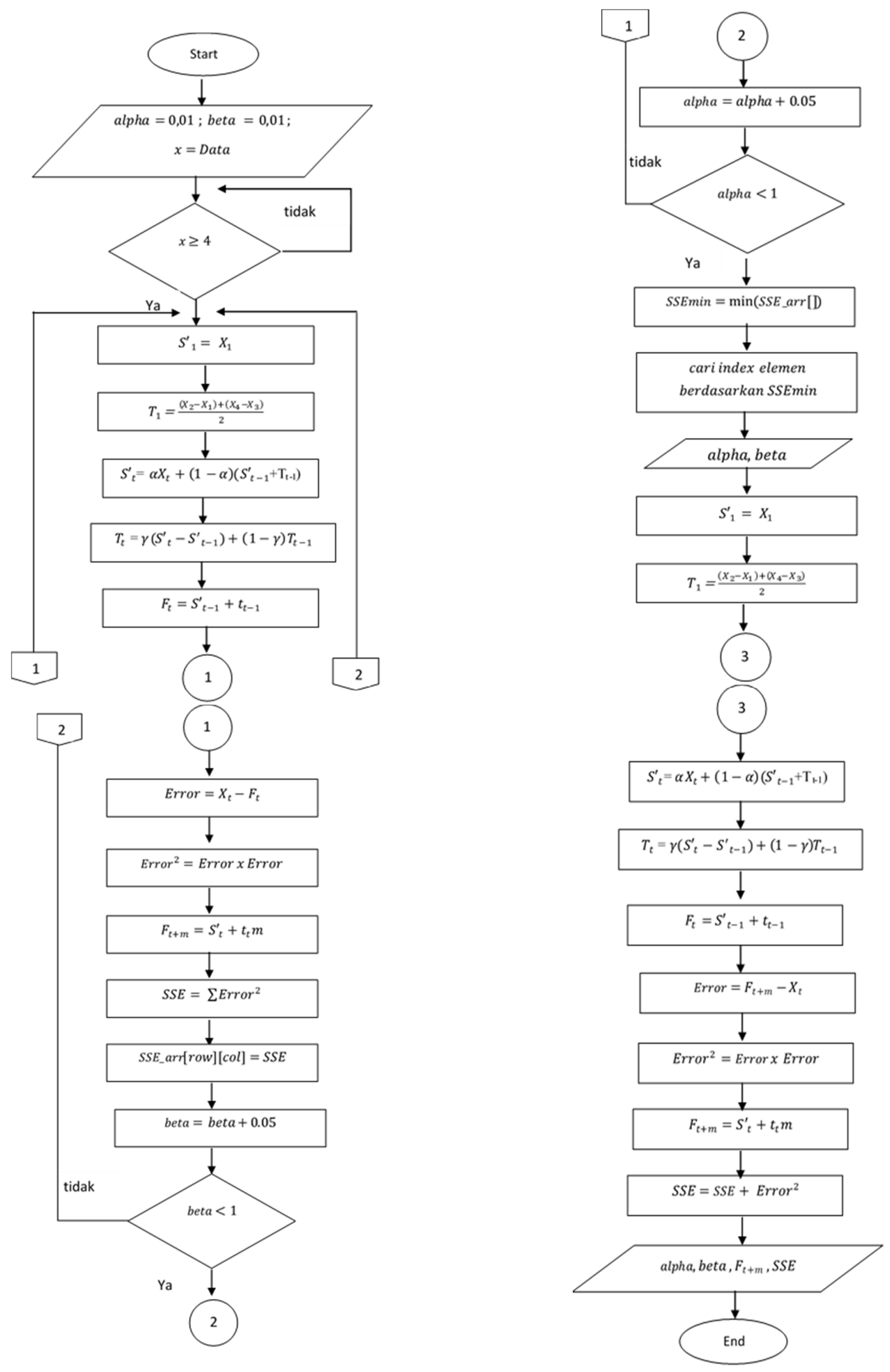

Gambar 1. Flowchart Double Exponential Smoothing Holt

$62 \mid \mathrm{H}$ a 1 a $\mathrm{m}$ a $\mathrm{n}$ 